\title{
Pengaruh Bauran Pemasaran Terhadap Loyalitas Pelanggan Zoya Cabang Medan Dengan Brand Image Sebagai Variabel Moderating
}

\author{
Lisa Anggi Nauli Siregar \\ Pascasarjana UIN Sumatera Utara Medan \\ lisasrg89@gmail.com
}

\begin{abstract}
Customer loyalty is customer loyalty to companies, brands and products, where this loyalty is influenced by various factors such as marketing mix, product, price, location and promotion and influenced by brand image as a moderating variable. This study aims to explain the effect of product, price, location and promotion on Zoya customer loyalty with brand image as a moderating variable. This research is quantitative research and the method to determine the sample is the Lemeshow formula with a sample size of 100 respondents. Data is obtained by distributing questionnaires that have been structured to the respondents. The data analysis technique used is the MRA (Moderating Regression Analysis). The results showed that as partially the product had a positive and significant effect on customer loyalty by $22.3 \%$, the price had a positive and significant effect on customer loyalty by $35.7 \%$, the location did not affect customer loyalty and promotion had a positive effect and significant to customer loyalty of $21.1 \%$. The prices, locations and promotions simultaneously have a positive and significant effect on customer loyalty. And products, prices, locations and promotions have a positive effect on customer loyalty by moderating the brand image in Zoya Medan Branch.
\end{abstract}

Keywords: Product, Price, Location, Promotion, Brand, Loyality

\begin{abstract}
Abstrak
Loyalitas pelanggan merupakan kesetiaan pelanggan terhadap perusahaan, merek maupun produk, dimana loyalitas ini dipengaruhi oleh berbagai faktor seperti bauran pemasaran yaitu, produk, harga, lokasi dan promosi serta dipengaruhi oleh brand image sebagai variabel moderasi. Penelitian ini bertujuan untuk menjelaskan pengaruh produk, harga, lokasi dan promosi terhadap loyalitas pelanggan Zoya dengan brand image sebagai variabel moderating. Penelitian ini merupakan penelitian kuantitatif dan metode yang digunakan untuk menentukan sampel adalah menggunakan rumus Lemeshow dengan ukuran sampel sebanyak 100 responden. Data diperoleh dengan penyebaran angket yang telah disusun secara terstruktur kepada responden. Teknik analisis data yang digunakan adalah uji MRA (Moderating Regresion Analysis). Hasil penelitian menunjukkan bahwa secara parsial produk berpengaruh positif dan signifikan terhadap loyalitas pelanggan sebesar $22,3 \%$, secara parsial harga berpengaruh positif dan signifikan terhadap loyalitas pelanggan sebesar $35,7 \%$, secara parsial lokasi tidak berpengaruh terhadap loyalitas pelanggan dan promosi secara parsial berpengaruh positif dan signifikan terhadap loyalitas pelanggan sebesar $21,1 \%$. Produk, harga, lokasi dan promosi secara simultan berpengaruh positif dan signifikan terhadap loyalitas pelanggan. Dan produk, harga, lokasi dan promosi berpengaruh positif terhadap loyalitas pelanggan dengan dimoderasi brand image di Zoya Cabang Medan.
\end{abstract}

Kata kunci: Produk, Harga, Lokasi, Promosi, Brand, Loyalitas 


\section{Pendahuluan}

Bauran pemasaran merupakan hal yang penting dalam menghadapi persaingan bisnis di era globalisasi. Hal ini dilakukan dengan memunculkan perbedaan dan keunikan yang dimiliki perusahaan dibadingkan dengan pesaing untuk dapat menarik minat konsumen untuk loyal terhadap produk perusahaan tersebut. Kesempatan untuk menarik pelanggan untuk menjadi loyal terdapat pada respon pada saat pelanggan melakukan pembelian yang pertama. Salah satu perusahaan yang menggunakan bauran pemasaran adalah Zoya. Zoya menyediakan kebutuhanwanita muslimah di Indonesia yang semakin senang menggunakan produk busana muslim. Dalam hal ini Islam pun mengajarkan kita tentang cara berpakaian yang baik. Zoya berkembang cukup pesat di beberapa daerah di Indonesia, salah satunya di Medan. Zoya di Medan didirikan pada tahun 2010. Seiring dengan munculnya brand kompetitor yang ada di Medan, Zoya menjaga eksistensinya di tengah persaingan bisnis fashion muslim dengan selalu memberikan service excellent kepada pelanggan.

Kegiatan pemasaran yang dilakukan Butik Zoya Busana Muslim di Medan berdasarkan pada konsep strategi pemasaran yang diterapkan untuk mencapai sasaran yang dituju pada industri pakaian. Bauran pemasaran yang dilakukan oleh Butik Zoya Busana Muslim di Medan berdasarkan pada konsep 4P yaitu, Produk (Product), Harga (Price), Tempat (Place) dan Promosi (Promotion). Zoya melengkapi muslimah Indonesia dengan berbagai jenis busana yang selalu mengikuti trend dunia. Tidak hanya bergaya modis, produk Zoya mengutamakan desain gaya yang ringan dan penuh warna.Strategi yang dilakukan Zoya dalam hal produk adalah melakukan inovasi dan variasi motif terbaru yang bisa diaplikasikan pada produk. Kulitas produk juga terjamin cool dan comfort dan sudah diberikan sertifikat dalam beberapa produk yang diproduksi oleh Zoya. ${ }^{1}$

Selain produk, harga juga memiliki peran penting dalam menjalankan usaha. Zoya melakukan strategi dalam hal harga dengan menawarkan harga yang terjangkau yang bisa dijangkau kalangan middle ke bawah. Zoya juga menawarkan harga yang bersaing dengan kompetitor. Zoya juga memberikan potongan harga untuk member yaitu, 10\% untuk regular member dan $20 \%$ untuk loyal member. Tempat atau lokasi dalam mendistribusikan produk juga harus diperhatikan secara baik oleh pelaku usaha. Zoya melakukan distribusi $\mathrm{O}$ to $\mathrm{O}$ 
yaitu Offline to Online atau sebaliknya. Artinya, pelanggan tidak harus datang ke toko untuk membeli produk Zoya, sehingga pelanggan yang ada di luar kota bisa belanja tanpa harus datang ke toko. Butik Zoya juga selalu memeriksa persediaan produk supaya tidak mengecewakan pelanggan. Promosi juga merupakan hal yang harus diperhatikan dalam mendistribusikan produk. Strategi promosi yang dilakukan Zoya bertema "Keep Beauty", yaitu menonjokan kecantikan wanita dengan pakaian dan jilbabnya. Zoya mendesain strategi ini untuk mendongkrak penjualan busana muslim dan mengajak perempuan-perempuan muslim menggunakan produk yang anggun dan elegan. ${ }^{2}$

Bauran pemasaran yang dilakukan di atas diharapkan dapat menigkatkan penjualan dan loyalitas pelanggan di Butik Zoya Medan.Selain bauran pemasaran, dalam penelitian ini loyalitas pelanggan juga dipengaruhi oleh brand image sebagai variabel moderating. Brand image menandakan tingkat kualitas tertentu suatu produk sehingga pembeli yang puas dapat dengan mudah memilih produk kembali. ${ }^{3}$ Butik Zoya Medan setiap tahunnya mengalami fluktuasi. Tahun 2011 sampai tahun 2014 pelanggan Butik Zoya Medan mengalami peningkatan. Tahun 2014 sampai tahun 2015 pelanggan Butik Zoya Medan mengalami penurunan. Tahun 2015 sampai tahun 2016 pelanggan Butik Zoya Medan meningkat kembali. Dan dari tahun 2016 sampai 2017 pelanggan Butik Zoya mengalami penurunan penjualan. ${ }^{4} \mathrm{a}$

\section{Kajian Teori}

\section{Teori Loyalitas Konsumen}

Oliver dalam Bob Foster menyatakan loyalitas konsumen adalah suatu komitmen yang mendalam untuk melakukan pembelian kembali atau berlangganan atas suatu produk atau pelayanan secara konsisten untuk masa datang, serta tidak terpengaruh pada lingkungan yang ada atau upaya-upaya yang ada atau upaya-upaya pemasaran yang dilakukan, serta hal-hal lain yang berpotensi pada kemungkinan berpindahnya si pelanggan ke perusahaan pesaing. ${ }^{5}$ Menurut Griffin dalam Hurriyati, loyalitas lebih mengacu pada wujud perilaku dari unit-unit pengambilan keputusan untuk melakukan pembelian secara terus menerus terhadap barang/jasa suatu perusahaan yang dipilih. Menurut Hurriyati, loyalitas adalah komitmen pelanggan bertahan secara mendalam untuk berlangganan kembali atau melakukan pembelian ulang produk/jasa terpilih 
secara konsisten dimasa yang akan datang, meskipun pengaruh ssituasi dan usahausaha pemasaran mempunyai potensi untuk menyebabkan perubahan perilaku. ${ }^{6}$ Loyalitas akan berlanjut hanya sepanjang pelanggan merasakan bahwa ia menerima nilai yang lebih baik (termasuk kualitas yang lebih tinggi dalam kaitannya dengan harga) dibandingkan dengan yang dapat diperoleh dengan beralih ke penyedia produk atau jasa lain. Jika perusahaan pertama tersebut melakukan sesuatu yang mengecewakan pelanggan atau jika pesaing mulai menawarkan nilai yang jauh lebih baik, risikonya adalah bahwa pelanggan tersebut akan menyeberang. ${ }^{7}$

Loyalitas dalam Islam disebut dengan al-wala. Secara etimologi, al-wala memiliki beberapa makna antara lain mencintai, menolong, mengikuti dan mendekat kepada sesuatu. Konsep loyalitas dalam Islam atau al-wala adalah ketundukan mutlak kepada Allah SWT dalam wujud menjalankan syariah Islam sepenuhnya. Loyalitas pelanggan dalam Islam terjadi apabila aktivitas muamalah itu dapat memberi manfaat yang saling menguntungkan kedua belah pihak, karena terpenuhinya kewajiban serta hak masing-masing melalui penerapan nilai-nilai Islam. ${ }^{8}$ Menurut Buchari Alma, karakteristik dari loyalitas adalah: 1. Konsumen melakukan pembelian ulang secara teratur atau regular. 2. Mereka juga membeli produk-produk lain bukan satu produk saja yang ditawarkan oleh satu produsen. 3. Mereka merekomendasikan teman-temannya untuk juga membeli produk yang sama ketempat yang sama. 4. Mereka tidak mudah beralih ke produk saingan. ${ }^{9}$

\section{Teori Bauran Pemasaran}

Bauran pemasaran (Marketing Mix) merupakan strategi kombinasi yang dialakukan oleh berbagai perusahaan dalam bidang pemasaran. Zaithmal and Bitner mengemukakan definisi bauran pemasaranadalah elemen-elemen organisasi perusahaan yang dapat dikontrol oleh perusahaan dalam melakukan komunikasi dengan konsumen dan akan dipakai untuk memuaskan konsumen. ${ }^{10}$ Definisi bauran pemasaran (marketing mix) menurut Kotler sebagai berikut : "Marketing mix is the set of marketing tools that the firm uses to pursue its marketing objective in the target market". Bauran pemasaran adalah sekumpulan alat pemasaran (marketing mix) yang dapat digunakan oleh perusahaan untuk mencapai tujuan pemasarannya dalam pasar sasaran. ${ }^{11}$ 


\section{Teori Produk}

Sebagian besar keuntungan yang didapat oleh perusahaan berasal dari kepuasan konsumen dalam menikmati produknya. Konsep produksi berpendapat bahwa konsumen akan menyukai produk yang berkualitas dengan harga yang relatif murah. Perusahaan dalam proses kegiatan produksi haruslah mengerti dan mengetahui dengan benar akan arti dari produk itu sendiri. Kotler dan Keller mengemukakan bahwa produk adalah segala sesuatu yang dapat ditawarkan kepada pasar untuk memuaskan suatu keinginan atau kebutuhan termasuk barang fisik, jasa, pengalaman, acara, orang, tempat, properti, organisasi, informasi dan ide. $^{12}$

Jika dilihat dalam perspektif syariah, produk yang akan dipasarkan haruslah produk yang halal dan memiliki mutu atau kualitas yang terbaik, bukan sebaliknya demi mendapatkan keuntungan yang berlipat kemudian menurunkan kualitas produk. ${ }^{13}$ Menurut Kotler dan Amstrong, kualitas produk (tangible products good quality) ditentukan oleh faktor-faktor : 1. Kinerja menunjukkan karakteristik fungsi dasar produk. 2. Penampilan fisik merupakan bentuk yang ditampilkan. 3. Kehandalan merupakan kekonsistenan suatu produk dapat digunakan. 4. Ukuran standar merupakan bahan baku produk terbuat dari bahanbahan menurut ukuran tertentu. 5. Kualitas merupakan umur teknik dan umur ekonomi produk. 6. Tingkat pelayanan merupakan kecepatan dan kemudahan dalam mendapatkan pelayanan baik sebelum maupun sesudah penjualan. 7 . Keindahan merupakan segi estetika dari bentuk fisik produk. 8. Kualitas relative merupakan akibat dari kurangnya pengetahuan pembeli akan ciri produk yang dibeli sehingga pembeli mengukur kualitas produk dari segi harga, merk, iklan dan reputasi perusahaan. ${ }^{14}$

\section{Teori Harga}

Kebijakan harga dipergunakan untuk merebut hati pembeli melalui produk perusahaan. Pada hakikatnya tujuan pemasaran itu adalah menciptakan permintaan atas suatu produk. Kebijakan bauran pemasaran merupakan alat yang dipergunakan untuk tujuan tersebut. Variabel harga di dalam marketing mix tidak kalah pentingnya dibandingkan dengan variabel-variabel lainnya. Penetapan harga atas suatu produk dapat menentukan apakah produk itu akan laku di pasar atau 
tidak. Dari sudut pandang konsumen harga biasanya didefinisikan sebagai apa yang harus diserahkan konsumen untuk membeli suatu produk atau jasa. ${ }^{15}$

Berdasarkan beberapa penetapan harga di atas, Kotler dan Keller menetapkan bahwa indikator dari harga adalah harga terjangkau, harga bersaing, kesesuaian harga dengan kualitas produk dan kesesuaian harga dengan manfaat. ${ }^{16}$ Penetapan harga dalam perspektif syariah,tidaklah terlalu rumit, dasar penetapan harga tertumpu pada besaran nilai atau harga suatu produk yang tidak boleh ditetapkan dengan berlipat-lipat besarnya, setelah dikurangi biaya. Konsep harga dalam perspektif syariah tidak berlandasan pada faktor keuntungan tetapi juga didasrkan pada aspek daya beli masyarakat dan kemaslahatan umat.

\section{Teori Place (Lokasi)}

Dalam bauran pemasaran, makna tempat lebih ditujukan pada penyaluran produk kepada konsumen. Perusahaan harus mencari cara terbaik untuk mendekatkan produknya kepada konsumen. Distribusi atau lokasi adalah suatu usaha atau upaya agar suatu produk dapat tersedia di tempat-tempat yang memudahkan konsumen membelinya setiap saat konsumen membutuhkan. ${ }^{17}$ Lokasi adalah tempat dimana sesuatu berada. Menurut Lupiyoadi lokasi merupakan keputusan yang dibuat perusahaan berkaitan dengan dimana operasi dan stafnya akan ditempatkan. Salah memilih lokasi perusahaan akan mengakibatkan kerugian bagi perusahaan. ${ }^{18}$

Kotler mengatakan bahwa perusahaan sebaiknya perlu secara matang mempertimbangkan pemilihan lokasi usaha untuk pengembangan di masa depan. Dari penelitian yang dilakukan Raharjani strategi lokasi adalah salah satu determinan yang paling penting dalam perilaku pembelian konsumen, pengecer harus memilih lokasi yang strategis dalam menempatkantokonya. Dapat disimpulkan bahwa lokasi adalah hal yang dipertimbangkan oleh konsumen. fasilitas yang dimilikinya dapat memenuhi kebutuhan konsumen. ${ }^{19}$ Menurut Hurriyati, pemilihan tempat atau lokasi memerlukan pertimbangan yang tepat terhadap beberapa faktor, yaitu: 1) Akses, misalnya lokasi yang mudah dijangkau sarana transportasi umum. 2) Visibilitas, misalnya lokasi yang dapat dilihat dengan jelas dari tepi jalan. 3) Lalu lintas (traffic), di mana ada dua hal yang perlu dipertimbangkan yaitu banyaknya orang yang lalu lalang dapat memberikan peluang besar terjadinya impulse buying dan kepadatan dan kemacetan lalu lintas 
dapat pula menjadi hambatan. 4) Tempat parkir yang luas dan aman. 5) Ekspansi, tersedia tempat yang cukup untuk perluasan usaha di kemudian hari. 6) Lingkungan, yaitu daerah sekitar yang mendukung jasa yang ditawarkan. 7) Persaingan, yaitu lokasi pesaing. 8) Peraturan pemerintah. ${ }^{20}$

Dalam perspektif syariah, lokasi bisa dimana saja, asalkan tempat tersebut bukan tempat yang dipersengketakan keberadaannya. Namun, Islam lebih menekankan pada kedekatan perusahaan dengan pasar. Hal itu untuk menghindari adanya aksi pencegatan barang sebelum sampai ke pasar.

\section{Teori Promosi}

Gilbert menyatakan bahwa promosi dapat saja merangsang konsumen mengunjungi toko, tetapi tampilan atau penatan produk oleh pengecer akan membuat perbedaan pada tingkat penjualan. ${ }^{21}$ Promosi dalam perspektif syariah merupakan suatu upaya penyampaian informasi yang benar terhadap produk barang atau jasa kepada calon konsumen. Berkaitan dengan hal ini, maka ajaran Islam sangat menekankan agar menghindari unsur-unsur penipuan atau memberikan informasi yang tidak benar kepada calon konsumen.

Menurut Kotler dan Amstrong bauran promosi adalah tatanan alat-alat pemasaran yang digunakan perusahaan untuk mencapai tujuan pemasarannya dalam pasar sasaran. Bauran promosi sebagai kombinasi perencanaan elemenelemen kegiatan promosi yang terdiri dari periklanan (advertising), promosi penjualan (sales promotion), penjualan pribadi (personal selling), hubungan masyarakat (publicity), pemasaran langsung (direct marketing). ${ }^{22}$

\section{Teori Brand Image}

Merek telah menjadi elemen yang krusial yang berkontribusi terhadap kesuksesan sebuah organisasi pemasaran, baik pemasaran bisnis maupun nirlaba, pemanfaatan maupun penyedia jasa, dan organisasi maupun global. ${ }^{23}$ Merek adalah wajah perusahaan untuk dunia, merek adalah nama perusahaan, bagaimana secara visual diekspresikan melalui logo dan bagaimana nama dan logo itu diperluas sepanjang suatu komunikasi organisasi. ${ }^{24}$ Menurut Aaker yang dikutip dari bukunya A.B Susanto dan Himawan menjelaskan pengertian merek adalah nama dan atau simbolyang bersifat membedakan (seperti sebuah logo, cap, atau kemasan) untuk mengidentifikasi barang atau jasa dari seorang penjual atau 
kelompok penjual tertentu, serta membedakannya dari barang atau jasayang dihasilkan para pesaing. Pada akhirnya, merek memberikan tanda mengenai sumber produk serta melindungi konsumen maupunprodusen dari para pesaing yang berusaha memberikan produk-produkyang tampak identik. ${ }^{25}$ Definisi merek menurut Keller sebagaimana yang dikutip oleh Fandy Tjiptono, merek adalah produk yang mampu memberikan dimensi tambahan yang secara unik membedakannya dari produk-produk lain yang dirancang untuk memuaskan kebutuhan serupa. $^{26}$

Keller mengatakan bahwa terdapat tiga hal yang dapat membedakan citra merek antara berbagai merek yang dievaluasioleh konsumen yang dapat meningkatkan kemungkinan untuk melakukan keputusan pembelian terhadap suatu merek, yaitu: 1. Favorability, dimana mengarah pada kemampuan merek tersebut untuk mudah diingat oleh pelanggan. Indikatornya adalah merek mudah diingat dan diucapkan, 2. Strength, merupakan kekuatan yang mengarah pada berbagai keunggulan-keunggulan yang dimiliki citra merek yang bersangkutan. Indikatornya adalah pengalaman perusahaan, keberfungsian semua fasilitas, dan 3 . Uniqueness, merupakan keunikan dari suatu merek produk yang dipandang lain dan memberikan citra (image) yang berbeda dari pesaing. Indikatornya adalah variasi produk.

\section{Metode Penelitian}

Pada penelitian ini, peneliti menggunakan pendekatan kuantitatif untuk memperoleh signifikasi pengaruh antar variabel yang diteliti yaitu bauran pemasaran (product, place, price dan promotion) terhadap loyalitas pelanggan Zoya Cabang Medan dengan brand image sebagai variabel moderating.

\section{Populasi dan Sampel}

Menurut Suharsimi Arikunto, "Populasi adalah keseluruhan subjek penelitian”. Apabila seseorang ingin meneliti semua elemen yang ada di wilayah penelitian, maka penelitiannya merupakan penelitian populasi. Studi atau penelitiannya juga disebut studi populasi atau sensus. ${ }^{27}$ Populasi pada penelitian ini adalah pelanggan yang melakukan transaksi di Butik Zoya Cabang Medan yang jumlahnya tidak diketahui. Menurut Suharsimi Arikunto "sampel adalah bagian dari jumlah dan karakteristik yang dimiliki oleh populasi tersebut". ${ }^{28}$ 
Karena keterbatasan waktu dan dana yang digunakan dalam penelitian ini, maka besarnya sampel ditetapkan dengan menggunakan rumus Lemeshow. ${ }^{29}$ Dengan menggunakan rumus Lemeshow didapat jumlah sampel yang akan dijadikan responden dalam penelitian ini sebanyak 100 responden. Dalam penelitian ini tekhnik pengambilan sample dilakukan secara acak sederhana (Simple Random Sampling), yaitu siapa saja pelangganyangmelakukan transaksi saat peneliti melakukan pengumpulan data melalui angket dapat digunakan menjadi sampel sebagai sumber data. Adapun alasan menggunakan teknik ini karena semua anggota populasi mempunyai kesempatan yang sama untuk menjadi anggota sampel.

\section{Data dan Sumber data}

Sumber data penelitian merupakan faktor penting yang menjadi pertimbangan dalam penentuan metode pengumpulan data. Data dalampenelitian ini dikumpulkan dari dua sumber yakni data primer dan data sekunder yang dilakukan pengambilan dengan metode wawancara dan angket/kuesioner. Hal ini dikarena dalam pengumpulannya, dimaksudkan agar data yang diperoleh bisa relevan dan up to date. Relevan disini maksudnya yaitu data memiliki hubungan langsung dengan penelitian. Sedangkan mutakhir yaitu data yang diperoleh masih up to date atau masih hangat dibicarakan. Dalam pengumpulan data, jenis data yang digunakan dalam penelitian adalah data primer. Data Primer adalah data yang diperoleh secara langsung dari masyarakat baik dilakukan melalui wawancara, observasi dan alat lainnya. Dalam penelitian ini untuk mendapatkan data primer dapat dilakukan dengan cara penyebaran angket/kuisioner langsung kepada pelanggan butik Zoya Cabang Medan. Kuesioner/angket dilakukan dengan mengumpulkan data tertulis berdasarkan jawaban dari responden atas pertanyaanpertanyaan.

\section{Hasil Penelitian}

\section{Uji Validitas}

Dari hasil uji validitas produk, harga, lokasi, loyalitas dan brand image dapat disimpulkan bahwa item pernyataan 1-6 adalah valid. Berdasarkan $\mathrm{r}$ hitung $>\mathrm{r}$ tabel, dimana $\mathrm{r}$ tabel untuk penelitian ini adalah sebesar 0,202. Hasil uji validitas dapat dilihat pada tabel berikut: 
Tabel 1 Hasil Uji Validitas Produk

\begin{tabular}{|c|c|c|c|}
\hline Pernyataan & r hitung & r tabel & Keterangan \\
\hline Item 1 & 0,537 & \multirow{6}{*}{$\begin{array}{c}\text { Instumen valid } \\
\text { jika } r \text { hitung }> \\
\text { r tabel, } r \\
\text { tabel }=0,202\end{array}$} & Valid \\
\hline Item 2 & 0,733 & & Valid \\
\hline Item 3 & 0,720 & & Valid \\
\hline Item 4 & 0,823 & & Valid \\
\hline Item 5 & 0,597 & & Valid \\
\hline Item 6 & 0,735 & & Valid \\
\hline
\end{tabular}

Tabel 2 Hasil Uji Validitas Harga

\begin{tabular}{|c|c|c|c|}
\hline Pernyataan & r hitung & $r$ tabel & Keterangan \\
\hline Item 1 & 0,742 & \multirow{6}{*}{$\begin{array}{c}\text { Instumen valid } \\
\text { jika } r \text { hitung }> \\
\text { r tabel, } r \\
\text { tabel }=0,202\end{array}$} & Valid \\
\hline Item 2 & 0,732 & & Valid \\
\hline Item 3 & 0,706 & & Valid \\
\hline Item 4 & 0,763 & & Valid \\
\hline Item 5 & 0,560 & & Valid \\
\hline Item 6 & 0,536 & & Valid \\
\hline
\end{tabular}

Tabel 3 Hasil Uji Validitas Lokasi

\begin{tabular}{|c|c|c|c|}
\hline Pernyataan & r hitung & r tabel & Keterangan \\
\hline Item 1 & 0,489 & Instrument & Valid \\
\cline { 1 - 1 } Item 2 & 0,609 & valid jika $\mathrm{r}$ & Valid \\
\cline { 1 - 2 } Item 3 & 0,683 & hitung $>\mathrm{r}$ & Valid \\
\cline { 1 - 1 } Item 4 & 0,608 & tabel, $\mathrm{r}$ tabel $=$ & Valid \\
& & 0,202 & \\
\hline
\end{tabular}

Tabel 4 Hasil Uji Validitas Promosi

\begin{tabular}{|c|c|c|c|}
\hline Pernyataan & r hitung & $r$ tabel & Keterangan \\
\hline Item 1 & 0,523 & \multirow{4}{*}{$\begin{array}{c}\text { Instrument } \\
\text { valid jika } \mathrm{r} \\
\text { hitung }>\mathrm{r} \\
\text { tabel, } \mathrm{r} \text { tabel= } \\
0,202\end{array}$} & Valid \\
\hline Item 2 & 0,661 & & Valid \\
\hline Item 3 & 0,598 & & Valid \\
\hline Item 4 & 0,563 & & Valid \\
\hline
\end{tabular}

Tabel 5 Hasil Uji Validitas Brand Image

\begin{tabular}{|c|c|c|c|}
\hline Pernyataan & r hitung & r tabel & Keterangan \\
\hline Item 1 & 0,408 & Instrument & Valid \\
\hline Item 2 & 0,495 & valid jika $r$ & Valid \\
\cline { 1 - 2 } Item 3 & 0,518 & hitung $>\mathrm{r}$ & Valid \\
\cline { 1 - 2 } Item 4 & 0,330 & tabel, $\mathrm{r}$ tabel $=$ & Valid \\
& & 0,202 & \\
\hline
\end{tabular}


Tabel 6 Hasil Uji Validitas Loyalitas

\begin{tabular}{|c|c|c|c|}
\hline Pernyataan & r hitung & r tabel & Keterangan \\
\hline Item 1 & 0,814 & Instumen valid & Valid \\
Item 2 & 0,828 & jika r hitung $>$ & Valid \\
Item 3 & 0,685 & r tabel, $r$ & tabel= \\
& 0,202 & Valid \\
Item 4 & 0,741 & & Valid \\
\hline Item 5 & 0,726 & & Valid \\
\hline Item 6 & 0,620 & & Valid \\
\hline
\end{tabular}

\section{Uji Reliabilitas}

Reliabilitas instrument angket yang digunakan dalam penelitian ini menggunakan program aplikasi SPSS dengan rumus Croncbach Alpha, jika Croncbach Alpha > 0.60 maka semua item pernyataan yang dianalisis dengan metode Alpha adalah reliabel.

Tabel 7 Hasil Uji Reliabilitas

\begin{tabular}{|c|c|c|c|}
\hline Variabel & $\begin{array}{c}\text { Croncbach } \\
\text { Alpha }\end{array}$ & $\begin{array}{c}\text { Tingkat } \\
\text { Kepercayaan }\end{array}$ & Keterangan \\
\hline Produk $\left(\mathrm{X}_{1}\right)$ & 0,881 & & Sangat Reliabel \\
\hline Harga $\left(\mathrm{X}_{2}\right)$ & 0,871 & \multirow{2}{*}{0,60} & Sangat Reliabel \\
\hline Lokasi $\left(\mathrm{X}_{3}\right)$ & 0,785 & & Reliabel \\
\hline Promosi $\left(\mathrm{X}_{4}\right)$ & 0,777 & & Reliabel \\
\hline BrandImage $\left(\mathrm{V}_{\mathrm{m}}\right)$ & 0,648 & & Cukup Reliabel \\
\hline Loyalitas $(\mathrm{Y})$ & 0,903 & & Sangat Reliabel \\
\hline
\end{tabular}

\section{Uji Normalitas}

Tabel 8 Uji Normalitas Kolmogrov-Smirnov

\begin{tabular}{|rr|r|r|r|r|r|r|}
\hline & & Produk & Harga & Lokasi & Promosi & \multicolumn{1}{|c|}{$\begin{array}{l}\text { Brand } \\
\text { Image }\end{array}$} & Loyalitas \\
\hline & $\mathrm{N}$ & 100 & 100 & 100 & 100 & 100 & 100 \\
Normal & Mean & 25,31 & 22,31 & 15,52 & 15,62 & 15,96 & 23,02 \\
Parameters ${ }^{\text {a,b }}$ & Std. & 3,047 & 3,440 & 2,291 & 2,041 & 1,847 & 4,171 \\
& & & & & & \\
Most Extreme & Absolute & 0,256 & 0,182 & 0,261 & 0,201 & 0,281 & 0,207 \\
Differences & Positive & 0,256 & 0,182 & 0,259 & 0,201 & 0,281 & 0,207 \\
& Negative & $-0,144$ & $-0,108$ & $-0,261$ & $-0,164$ & $-0,149$ & $-0,188$ \\
Kolmogorov-Smirnov Z & 2,564 & 1,816 & 2,608 & 2,055 & 2,814 & 2,071 \\
Asymp. Sig. (2-tailed) & 0,190 & 0,164 & 0,069 & 0,174 & 0,203 & 0,258 \\
\hline
\end{tabular}

a. Test distribution is Normal.

b. Calculated From data.

Pada uji Kolmogrov-Smirnov di atas dapat dilihat bahwa signifikansi seluruh variabel berada di atas batas standar yaitu 0,05 . Hasil menunjukkan: 
a. Produk sebesar 0,190, $019>0,05$. Hal ini membuktikan bahwa data dari variabel produk memiliki distribusi yang normal dan dapat dilanjutkan untuk pengujian asumsi klasik yang lainnya.

b. Harga sebesar 0,164, 0,164>0,05. Hal ini membuktikan bahwa data dari variabel harga memiliki distribusi yang normal dan dapat dilanjutkan untuk pengujian asumsi klasik.

c. Lokasi sebesar 0,069, 0,069 >0,05. Hal ini membuktikan bahwa data dari variabel lokasi memiliki distribusi yang normal dan dapat dilanjutkan untuk pengujian asumsi klasik.

d. Promosi sebesar 0,174, 0,174 >0,05. Hal ini membuktikan bahwa data dari variabel promosi memiliki distribusi yang normal dan dapat dilanjutkan untuk pengujian asumsi klasik.

e. Brand image sebesar 0,203, 0,203 > 0,05. Hal ini membuktikan bahwa data dari variabel brand image memiliki distribusi yang normal dan dapat dilanjutkan untuk pengujian asumsi klasik.

f. Loyalitas sebesar 0,258, 0,258 >0,05. Hal ini membuktikan bahwa data dari variabel loyalitas memiliki distribusi yang normal dan dapat dilanjutkan untuk pengujian asumsi klasik.

\section{Uji Multikolinearitas}

\section{Tabel 9 Uji Multikolinearitas}

\begin{tabular}{|c|c|c|c|c|c|c|c|}
\hline \multirow[t]{2}{*}{ Model } & \multicolumn{2}{|c|}{$\begin{array}{c}\text { Unstandardized } \\
\text { Coefficients }\end{array}$} & \multirow{2}{*}{$\begin{array}{c}\text { Standardized } \\
\text { Coefficients }\end{array}$} & \multirow[t]{2}{*}{$\mathbf{T}$} & \multirow[t]{2}{*}{ Sig. } & \multicolumn{2}{|c|}{$\begin{array}{c}\text { Collinearity } \\
\text { Statistics } \\
\end{array}$} \\
\hline & B & Std. Error & & & & Tolerance & VIF \\
\hline (Constant) & $-1,889$ & 3,668 & & $-0,515$ & 0,608 & & \\
\hline Produk & 0,306 & 0,120 & 0,223 & 2,556 & 0,012 & 0,841 & 1,189 \\
\hline Harga & 0,433 & 0,116 & 0,357 & 3,748 & 0,000 & 0,707 & 1,415 \\
\hline Lokasi & 0,046 & 0,176 & 0,023 & 0,263 & 0,793 & 0,827 & 1,209 \\
\hline Promosi & 0,435 & 0,196 & 0,211 & 2,222 & 0,029 & 0,713 & 1,402 \\
\hline
\end{tabular}

a. Dependent Variable: loyalitas

Berdasarkan tabel di atas dapat diketahui nilai VIF dan tolerance masingmasing variabel adalah sebagai berikut:

a. Nilai VIF Produk adalah $1,189<10$ dan tolerancenya adalah 0,841 > 0,1 artinya tidak terjadi multikolinearitas

b. Nilai VIF Hargaadalah 1,415 < 10 dan tolerancenya adalah 0,707 > 0,1 artinya tidak terjadi multikolinearitas 
c. Nilai VIF Lokasi adalah $1,209<10$ dan tolerancenya adalah $0,827>0,1$ artinya tidak terjadi multikolinearitas

d. Nilai Promosi adalah 1,402 < 10 dan tolerancenya adalah $0,713>0,1$ artinya tidak terjadi multikolinearitas

Uji Koefisien Determinasi $\left(\mathbf{R}^{2}\right)$

Tabel 10 Uji $\mathbf{R}^{2}$

\begin{tabular}{|r|r|r|r|r|}
\hline Model & R & R Square & $\begin{array}{c}\text { Adjusted R } \\
\text { Square }\end{array}$ & \multicolumn{1}{|c|}{$\begin{array}{c}\text { Std. Error of the } \\
\text { Estimate }\end{array}$} \\
\hline 1 & $0,624^{\mathrm{a}}$ & 0,390 & 0,364 & 3,326 \\
2 & $0,632^{\mathrm{b}}$ & 0,399 & 0,367 & 3,318 \\
3 & $0,708^{\mathrm{c}}$ & 0,501 & 0,451 & 3,090 \\
\hline
\end{tabular}

a. Predictors: (Constant), promosi, lokasi, produk, harga

b. Predictors: (Constant), promosi, lokasi, produk, harga, brand_image

c. Predictors: (Constant), promosi, lokasi, produk, harga, brand_image, brand_harga, brand_lokasi, brand_produk, brand_promosi

d. Dependent Variable: loyalitas

Koefisien determinasi $\left(\mathrm{R}^{2}\right)$ pada intinya mengukur seberapa jauh kemampuan model dalam menerangkan variasi variabel terikat. Berdasarkan perhitungan dengan menggunakan SPSS diperoleh angka adjusted R square untuk model penelitian pertama adalah 0,364 atau 36,4 \%. Hal ini menunjukkan bahwa persentase pengaruh variabel independen terhadap variabel dependen sebesar 36,4 $\%$. Sedangkan sisanya sebesar $63,6 \%$ dijelaskan oleh variabel lain yang tidak dimasukkan dalam penelitian ini.Adjust $\mathrm{R}$ square untuk model penelitian kedua adalah 0,367 atau $36,7 \%$. Hal ini menunjukkan bahwa persentase pengaruh variabel independen variabel dependen serta variabel moderating sebesar 36,7\%. Sedangkan sisanya sebesar 63,3\% dijelaskan oleh variabel lain yang tidak dimasukkan ke dalam penelitian ini. Adjust R square untuk model penelitian ketiga adalah 0,451 atau 45,1\%. Hal ini menunjukkan bahwa persentase pengaruh interaksi variabel independen dengan variabel moderating terhadap variabel dependen sebesar 45,1\%. Sedangkan sisanya 54,9\% dijelaskan oleh variabel lain yang tidak dimasukkan dalam penelitian ini. 
Tabel 11 Hasil Uji t

\begin{tabular}{|l|r|r|r|r|r|}
\hline \multirow{2}{*}{ Model } & \multicolumn{2}{|c|}{$\begin{array}{c}\text { Unstandardized } \\
\text { Coefficients }\end{array}$} & $\begin{array}{c}\text { Standardized } \\
\text { Coefficients }\end{array}$ & \multicolumn{1}{c|}{ Sig. } & \\
\cline { 2 - 3 } & \multicolumn{1}{|c|}{ B } & Std. Error & \multicolumn{1}{c|}{ Beta } & & \\
\hline 1 (Constant) & $-1,889$ & 3,668 & & $-0,515$ & 0,608 \\
Produk & 0,306 & 0,120 & 0,223 & 2,556 & 0,012 \\
Harga & 0,433 & 0,116 & 0,357 & 3,748 & 0,000 \\
Lokasi & 0,046 & 0,176 & 0,023 & 0,263 & 0,793 \\
Promosi & 0,435 & 0,196 & 0,211 & 2,222 & 0,029 \\
\hline (Constant) & $-3,696$ & 3,950 & & $-0,936$ & 0,352 \\
Produk & 0,304 & 0,119 & 0,222 & 2,546 & 0,013 \\
Harga & 0,386 & 0,122 & 0,319 & 3,178 & 0,002 \\
Lokasi & 0,054 & 0,175 & 0,027 & 0,307 & 0,760 \\
Promosi & 0,326 & 0,215 & 0,158 & 1,521 & 0,132 \\
brand_image & 0,280 & 0,231 & 0,124 & 1,214 & 0,228 \\
\hline 3 Constant) & $-16,244$ & 26,858 & & $-0,605$ & 0,547 \\
Produk & $-0,217$ & 1,072 & $-0,159$ & $-0,203$ & 0,840 \\
Harga & 3,722 & 1,258 & 3,070 & 2,957 & 0,004 \\
Lokasi & $-3,694$ & 1,420 & $-1,852$ & $-2,601$ & 0,011 \\
Promosi & 0,966 & 1,710 & 0,469 & 0,565 & 0,573 \\
brand_image & 0,900 & 1,660 & 0,399 & 0,542 & 0,589 \\
brand_produk & 0,033 & 0,067 & 0,602 & 0,497 & 0,621 \\
brand_harga & $-0,215$ & 0,083 & $-4,390$ & $-2,599$ & 0,011 \\
brand_lokasi & 0,245 & 0,091 & 2,915 & 2,705 & 0,008 \\
brand_promosi & $-0,030$ & 0,111 & $-0,393$ & $-0,269$ & 0,789 \\
\hline
\end{tabular}

a. Dependent Variable: loyalitas

Berdasarkan perhitungan menggunakan SPSS terdapat 3 model untuk dianalisis uji parsialnya, yaitu:

a. Model I

Berdasarkan tabel di atas dasar pengambilan keputusan adalah dengan membandingkan $\mathrm{t}$ tabel dengan $\mathrm{t}$ hitung. $\mathrm{T}$ tabel dalam penelitian ini adalah 1,661. Jika $\mathrm{t}$ hitung $>\mathrm{t}$ tabel dan nilai sig $<0,05$ maka variabel independen (produk, harga, lokasi dan promosi)berpengaruh signifikan secara parsial terhadap variabel dependen (loyalitas).

1) Produk, nilai t hitung sebesar 2,556 dan nilai sig sebesar 0,012. 2,556>1,661 dan $0,012<0,05$. Artinya produk secara parsial berpengaruh signifikan dan positif terhadap loyalitas pelanggan. Nilai beta 0,223 atau 22, 3\% menunjukkan bahwa produk memiliki pengaruh sebesar 22,3\% terhadap loyalitas pelanggan Zoya cabang Medan 
2) Harga, nilai t hitung sebesar 3,748 dan nilai sig sebesar 0,000. 3,748 > 1,661 dan $0,000>0,05$. Artinya harga secara parsial berpengaruh signifikan dan positif terhadap loyalitas pelanggan. Nilai beta 0,357 atau $35,7 \%$ menunjukkan bahwa harga memiliki pengaruh sebesar $35,7 \%$ terhadap loyalitas pelanggan Zoya cabang Medan

3) Lokasi, nilai t hitung sebesar 0,263 dan nilai sig sebesar 0,793. 0,263 < 1,661 dan $0,793>0,05$. Artinya lokasi secara parsial tidak memiliki pengaruh yang signifikan terhadap loyalitas pelanggan. Nilai beta 0,023 atau $2,3 \%$ menunjukkan bahwa lokasi memiliki kontribusi sebesar 2,3\% terhadap loyalitas pelanggan Zoya cabang Medan

4) Promosi, nilai t hitung sebesar 2,222 dan nilai sig 0,029. 2,222>1,661 dan $0,029<0,05$. Artinya promosi berpengaruh signifikan dan positif terhadap loyalitas pelanggan. Nilai beta 0,211 atau $21,1 \%$ menunjukkan bahwa promosi memiliki pengaruh sebesar 21,1\% terhadap loyalitas pelanggan Zoya cabang Medan

b. Model II

Berdasarkan tabel di atas dasar pengambilan keputusan adalah dengan membandingkan $\mathrm{t}$ tabel dengan $\mathrm{t}$ hitung. $\mathrm{T}$ tabel dalam penelitian ini adalah 1,664. Jika t hitung $>\mathrm{t}$ tabel dan nilai sig $<0,05$ maka variabel independen (produk, harga, lokasi dan promosi)berpengaruh signifikan secara parsial terhadap variabel dependen (loyalitas), serta brand image berpengaruh signifikan secara parsial terhadap loyalitas.

1) Produk, nilai t hitung sebesar 2,546 dan nilai sig sebesar 0,013. 2,556 > 1,661 dan $0,012<0,05$. Artinya produk secara parsial berpengaruh signifikan dan positif terhadap loyalitas pelanggan. Nilai beta 0,222 atau 22,2\% menunjukkan bahwa produk memiliki pengaruh sebesar 22,2\% terhadap loyalitas pelanggan Zoya cabang Medan

2) Harga, nilai t hitung sebesar 3,178 dan nilai sig sebesar 0,002. 3,178 > 1,661 dan 0,002>0,05. Artinya harga secara parsial berpengaruh signifikan dan positif terhadap loyalitas pelanggan. Nilai beta 0,319 atau $31,9 \%$ menunjukkan bahwa harga memiliki pengaruh sebesar 31,9\% terhadap loyalitas pelanggan Zoya cabang Medan

3) Lokasi, nilai t hitung sebesar 0,307 dan nilai sig sebesar 0,760. 0,307 < 1,661 dan $0,760>0,05$. Artinya lokasi secara parsial tidak memiliki pengaruh yang 
signifikan terhadap loyalitas pelanggan. Nilai beta 0,027 atau 2,7\% menunjukkan bahwa lokasi memiliki kontribusi sebesar 2,7\% terhadap loyalitas pelanggan Zoya cabang Medan

4) Promosi, nilai t hitung sebesar 1,521 dan nilai sig 0,137. 1,521 < 1,661 dan $0,137>0,05$. Artinya promosi secara parsial tidak berpengaruh signifikan terhadap loyalitas pelanggan. Nilai beta 0,158 atau $15,8 \%$ menunjukkan bahwa promosi memiliki kontribusi sebesar 15,8\% terhadap loyalitas pelanggan Zoya cabang Medan

5) Brand image, nilai t hitung sebesar 1,214 dan nilai sig 0,228. 1,214<1,661 dan $0,228>0,05$. Artinya brand image secara parsial tidak berpengaruh signifikan terhadap loyalitas pelanggan. Nilai beta sebesar 0,124 atau 12,4\% menunjukkan bahwa brand image memiliki kontribusi sebesar 12,4\% terhadap loyalitas pelanggan Zoya cabang Medan

c. Model III

Berdasarkan tabel di atas dasar pengambilan keputusan adalah dengan membandingkan $\mathrm{t}$ tabel dengan $\mathrm{t}$ hitung. $\mathrm{T}$ tabel dalam penelitian ini adalah 1,661. Jika t hitung > t tabel dan nilai sig < 0,05 maka variabel independen (produk, harga, lokasi dan promosi) berpengaruh signifikan secara parsial terhadap variabel dependen (loyalitas), serta brand image berpengaruh signifikan secara parsial terhadap loyalitas. Dan uji interaksi antara variabel independen (produk, harga, lokasi dan promosi) dengan variabel moderating (brand image) terhadap variabel dependen (loyalitas).

1) Produk, nilai t hitung sebesar 0,203 dan nilai sig sebesar 0,840. 0,203 < 1,661, dan $0,840>0,05$. Artinya produk secara parsial tidak berpengaruh signifikan terhadap loyalitas pelanggan. Nilai beta sebesar $-0,159$ atau 15, 9\%. Artinya produk memberikan kontribusi sebesar 15,9 \% terhadap loyalitas pelanggan Zoya cabang Medan

2) Harga, nilai t hitung sebesar 2,957 dan nilai sig sebesar 0,004. 2,597> 1,661 dan $0,004<0,05$. Artinya harga secara parsial memiliki pengaruh yang signifikan dan positif terhadap loyalitas pelanggan. Nilai beta sebesar 3,070 atau $307 \%$. Artinya harga memberikan kontribusi sebesar $307 \%$ terhadap loyalitas pelanggan Zoya cabang Medan

3) Lokasi, nilai t hitung sebesar 2,601 dan nilai sig sebesar 0,011. 2,601 > 1,661 dan $0,011<0,05$. Artinya lokasi secara parsial memiliki pengaruh yang 
signifikan terhadap loyalitas pelanggan. Nilai beta 1,852 atau $185,2 \%$. Artinya lokasi memiliki kontribusi sebesar $182,5 \%$ terhadap loyalitas pelanggan Zoya cabang Medan

4) Promosi, nilai t hitung sebesar 0,565 dan nilai sig sebesar 0,573. 0,565 < 1,661 dan $0,573>0,05$. Artinya promosi secara parsial tidak berpengaruh signifikan terhadap loyalitas pelanggan. Nilai beta sebesar 0,469 atau 46,9\%. Artinya promosi memiliki kontribusi sebesar $46,9 \%$ terhadap loyalitas pelanggan Zoya cabang Medan

5) Brand image, nilai t hitung sebesar 0,542 dan nilai sig sebesar 0,589. 0,542 < 1,661 dan 0,582 >0,05. Artinya brand image secara parsial tidak memiliki pengaruh yang signifikan terhadap loyalitas pelanggan. Nilai beta sebesar 0,399 atau 39,9\%. Artinya brand image memiliki kontribusi sebesar 39,9\% terhadap loyalitas pelanggan Zoya cabang Medan

6) Brand_produk, nilai t hitung sebesar 0,497 dan nilai sig sebesar 0,621. 0,497 < 1,661 dan 0,621 >0,05. Artinya brand_produk secara parsial tidak mempengaruhi loyalitas pelanggan. Hal ini menyatakan brand image bukan variabel moderasi. Nilai beta sebesar 0,601 atau 60,1\%. Artinya brand_produk memberikan kontribusi sebesar 60,1\% terhadap loyalitas pelanggan Zoya cabang Medan

7) Brand_harga, nilai t hitung sebesar 2,599 dan nilai sig 0,011. 2,599>1,661 dan $0,011<0,05$. Artinya brand_harga secara parsial memiliki pengaruh yang signifikan terhadap loyalitas pelanggan. Hal ini menyatakan brand image adalah variabel moderasi. Nilai beta sebesar 4,390 atau $439 \%$. Artinya brand_harga memiliki kontribusi sebesar $439 \%$ terhadap loyalitas pelanggan Zoya cabang Medan

8) Brand_lokasi, nilai t hitung sebesar 2,705 dan nilai sig 0,008. 2,705 > 1,664 dan $0,008<0,05$. Artinya brand_lokasi secara parsial memiliki pengaruh yang signifikan terhadap loyalitas pelanggan. Hal ini menyatakan brand image adalah variabel moderasi. Nilai beta sebesar 2,915 atau 291,5\%. Artinya brand_lokasi memiliki kontribusi sebesar 291,5\% terhadap loyalitas pelanggan zoya cabang Medan

9) Brand_promosi, nilai t hitung sebesar 0,269 dan nilai sig 0,789. 0,269 < 1,661 dan $0,789>0,05$. Artinya brand_promosi secara parsial tidak memiliki pengaruh yang signifikan terhadap loyalitas pelanggan. Hal ini menyatakan 
brand image bukan variabel moderasi. Nilai beta sebesar 0,393 atau 39,3\%. Artinya brand_promosi memiliki kontribusi sebesar 39,3\% terhadap loyalitas pelanggan Zoya cabang Medan.

\section{Uji Simultan (Uji F)}

Tabel 12 Hasil Uji F

\begin{tabular}{|rr|r|r|r|r|r|}
\hline \multicolumn{1}{|l|}{ Model } & $\begin{array}{c}\text { Sum of } \\
\text { Squares }\end{array}$ & Df & $\begin{array}{c}\text { Mean } \\
\text { Square }\end{array}$ & F & Sig. \\
\hline 1 & Regression & 670,878 & 4 & 167,719 & 15,159 &, $000^{\mathrm{a}}$ \\
& Residual & 1051,082 & 95 & 11,064 & & \\
& Total & 1721,960 & 99 & & & \\
\hline 2 & Regression & 687,100 & 5 & 137,420 & 12,482 & $0,000^{\mathrm{b}}$ \\
& Residual & 1034,860 & 94 & 11,009 & & \\
& Total & 1721,960 & 99 & & & \\
\hline 3 & Regression & 862,430 & 9 & 95,826 & 10,034 & $0,000^{\mathrm{c}}$ \\
& Residual & 859,530 & 90 & 9,550 & & \\
& Total & 1721,960 & 99 & & & \\
\hline
\end{tabular}

a. Predictors: (Constant), promosi, lokasi, produk, harga

b. Predictors: (Constant), promosi, lokasi, produk, harga, brand_image c. Predictors: (Constant), promosi, lokasi, produk, harga, brand_image, brand_harga, brand_lokasi, brand_produk, brand_promosi

d. Dependent Variable: loyalitas

Berdasarkan Perhitungan menggunakan SPSS dapat dilihat bahwa nilai F hitung untuk model I adalah 15,159 dan nilai sig sebesar 0,000. Nilai f tabel untuk model i adalah sebesar 2,312. Sehingga diperoleh bahwa F hitung $>\mathrm{F}$ tabel yaitu 15,159>2,312 dan 0,000<0,05, maka dapat diambil kesimpulan bahwa produk, harga, lokasi dan promosi secara simultan memiliki pengaruh yang signifikan dan positif terhadap loyalitas pelanggan zoya cabang Medan. Model II nilai $\mathrm{F}$ hitung sebesar 12,482 dan nilai sig sebesar 0,000. Nilai $\mathrm{F}$ tabel untuk model ii adalah 2,311 Sehingga 12,482 > 2,311 dan 0,000 $<0,05$, maka disimpulkan bahwa produk, harga, lokasi, promosi dan brand image secara simultan memiliki pengaruh yang signifikan dan positif terhadap loyalitas pelanggan zoya cabang Medan. Model III nilai F hitung sebesar10,034 dan nilai sig sebesar 0,000. Nilai $\mathrm{F}$ tabel untuk model iii adalah 1,985 sehingga 10,034> 1,985 dan 0,000 < 0,05, maka disimpulkan bahwa produk, harga, lokasi, promosi, brand image, brand_produk, brand_harga, brand_lokasi, brand_promosi secara simultan memiliki pengaruh yang signifikan dan positif terhadap loyalitas pelanggan zoya cabang Medan. 
Analisis MRA (Moderating Regression Analysis) Tabel 13 Hasil Regresi Berganda

\begin{tabular}{|l|r|r|r|r|r|}
\hline \multirow{2}{*}{ Model } & \multicolumn{2}{|c|}{$\begin{array}{c}\text { Unstandardized } \\
\text { Coefficients }\end{array}$} & $\begin{array}{c}\text { Standardized } \\
\text { Coefficients }\end{array}$ & \multicolumn{1}{c|}{ t } & \\
\cline { 2 - 4 } & \multicolumn{1}{|c|}{ B } & \multicolumn{1}{c|}{$\begin{array}{c}\text { Std. } \\
\text { Error }\end{array}$} & \multicolumn{1}{c|}{ Beta } & & \\
\hline 1 (Constant) & $-1,889$ & 3,668 & & $-0,515$ & 0,608 \\
Produk & 0,306 & 0,120 & 0,223 & 2,556 & 0,012 \\
Harga & 0,433 & 0,116 & 0,357 & 3,748 & 0,000 \\
Lokasi & 0,046 & 0,176 & 0,023 & 0,263 & 0,793 \\
Promosi & 0,435 & 0,196 & 0,211 & 2,222 & 0,029 \\
\hline 2 Constant) & $-3,696$ & 3,950 & & $-0,936$ & 0,352 \\
Produk & 0,304 & 0,119 & 0,222 & 2,546 & 0,013 \\
Harga & 0,386 & 0,122 & 0,319 & 3,178 & 0,002 \\
Lokasi & 0,054 & 0,175 & 0,027 & 0,307 & 0,760 \\
Promosi & 0,326 & 0,215 & 0,158 & 1,521 & 0,132 \\
brand_image & 0,280 & 0,231 & 0,124 & 1,214 & 0,228 \\
\hline 3 Constant) & $-16,244$ & 26,858 & & $-0,605$ & 0,547 \\
Produk & $-0,217$ & 1,072 & $-0,159$ & $-0,203$ & 0,840 \\
Harga & 3,722 & 1,258 & 3,070 & 2,957 & 0,004 \\
Lokasi & $-3,694$ & 1,420 & $-1,852$ & $-2,601$ & 0,011 \\
Promosi & 0,966 & 1,710 & 0,469 & 0,565 & 0,573 \\
brand_image & 0,900 & 1,660 & 0,399 & 0,542 & 0,589 \\
brand_produk & 0,033 & 0,067 & 0,602 & 0,497 & 0,621 \\
brand_harga & $-0,215$ & 0,083 & $-4,390$ & $-2,599$ & 0,011 \\
brand_lokasi & 0,245 & 0,091 & 2,915 & 2,705 & 0,008 \\
brand_promosi & $-0,030$ & 0,111 & $-0,393$ & $-0,269$ & 0,789 \\
\hline
\end{tabular}

a. Dependent Variable: loyalitas

1. Model I

Persamaan regresinya sebagai berikut:

$$
\mathrm{Y}_{\text {loyalitas }}=\mathrm{a}+\mathrm{b}_{\text {1produk }}+\mathrm{b}_{2 \text { harga }}+\mathrm{b}_{3 \text { lokasi }}+\mathrm{b}_{4 \text { promosi }}+\mathrm{e}
$$

Sehingga persamaan regresinya:

$$
Y_{\text {loyalitas }}=-1,889+0,306_{\text {Prod }}+0,433_{\text {har }}+0,046_{\text {lok }}+0,435_{\text {prom }}+\mathrm{e}
$$

Penjelasan regresi tersebut adalah sebagai berikut:

a. Konstanta sebesar $-1,889$, artinya apabila variabel produk, harga, lokasi dan promosi dianggap konstan atau 0 maka loyalitas pelanggan di Zoya Cabang Medan akan menurun adalah sebesar 1,889 
b. Koefisien regresi produk sebesar 0,306 artinya apabila variabel produk ditambah $1 \%$ dan variabel yang lain di anggap tetap maka loyalitas pelanggan di Zoya Cabang Medan meningkat sebesar 30,6\%

c. Koefisien regresi harga sebesar 0,433 artinya apabila variabel harga ditambah $1 \%$ dan variabel yang lain di anggap tetap maka loyalitas pelanggan di Zoya Cabang Medan meningkat sebesar 43,3\%

d. Koefisien regresi lokasi sebesar 0,046 artinya apabila variabel lokasi ditambah $1 \%$ dan variabel yang lain di anggap tetap maka loyalitas pelanggan di Zoya Cabang Medan meningkat sebesar 4,6\%

e. Koefisien regresi promosi sebesar 0,435 artinya apabila variabel promosi ditambah $1 \%$ dan variabel yang lain di anggap tetap maka loyalitas pelanggan di Zoya Cabang Medan meningkat sebesar 43,5\%.

\section{Model II}

Persamaan regresinya sebagai berikut:

$$
\mathrm{Y}_{\text {loyalitas }}=\mathrm{a}+\mathrm{b}_{\text {1produk }}+\mathrm{b}_{2 \text { harga }}+\mathrm{b}_{3 \text { lokasi }}+\mathrm{b}_{4 \text { promosi }}+\mathrm{b}_{5 \text { brand image }}+\mathrm{e}
$$

Sehingga persamaan regresinya:

$$
\begin{gathered}
Y_{\text {loyalitas }}=-3,696+0,304_{\text {Produk }}+0,386_{\text {harga }}+0,054_{\text {lokasi }}+0,326_{\text {promosi }}+0,280_{\text {brand }} \\
\text { image }+ \text { e }
\end{gathered}
$$

Penjelasan regresi tersebut adalah sebagai berikut:

a. Konstanta sebesar 3,696, artinya apabila variabel produk, harga, lokasi promosi dan brand image dianggap konstan atau 0 maka loyalitas pelanggan di Zoya Cabang Medan akan menurun sebesar 3,696

b. Koefisien regresi produk sebesar 0,304 artinya apabila variabel produk ditambah $1 \%$ dan variabel yang lain di anggap tetap maka loyalitas pelanggan akan meningkat sebesar $30,4 \%$

c. Koefisien regresi harga sebesar 0,387 artinya apabila variabel harga ditambah $1 \%$ dan variabel lain dianggap tetap maka loyalitas pelanggan akan meningkat sebesar $38,7 \%$.

d. Koefisien regresi lokasi sebesar 0,054 artinya apabila variabel lokasi ditambah $1 \%$ dan variabel yang lain di anggap tetap maka loyalitas pelanggan di Zoya Cabang Medan meningkat sebesar 5,4\%. 
e. Koefisien regresi promosi sebesar 0,326 artinya apabila variabel promosi ditambah $1 \%$ dan variabel yang lain di anggap tetap maka loyalitas pelanggan di Zoya Cabang Medan meningkat sebesar 32,6\%.

f. Koefisien regresi brand image sebesar 0,280 artinya apabila variabel brand image ditambah $1 \%$ dan variabel yang lain di anggap tetap maka loyalitas pelanggan di Zoya Cabang Medan meningkat sebesar 28\%.

3. Model III

Persamaan regresinya sebagai berikut:

$$
\begin{aligned}
Y_{\text {loyalitas }}= & a+b_{1 \text { produk }}+b_{2 \text { harga }}+b_{3 \text { lokasi }}+b_{4 \text { promosi }}+b_{5 \text { brand image }}+b_{6 \text { brand_produk }} \\
& +b_{7 \text { brand_harga }}+b_{8 \text { brand_lokasi }}+b_{9 \text { brand_promosi }}+\mathrm{e}
\end{aligned}
$$

Sehingga persamaan regresinya:

$$
\begin{aligned}
Y_{\text {loyalitas }}= & -16,244-0,217_{\text {Produk }}+3,772_{\text {harga }}-3,694_{\text {lokasi }}+0,966_{\text {promosi }}+ \\
& 0,900_{\text {brand image }}+0,033_{\text {brand_produk }}-0,215_{\text {brand_harga }}+0,245_{\text {brand_lokasi }} \\
& -0,030_{\text {brand_promosi }}+\mathrm{e}
\end{aligned}
$$

Penjelasan regresi tersebut adalah sebagai berikut:

a. Konstanta sebesar 16,244, artinya apabila variabel produk, harga, lokasi promosi, brand image, brand_produk, brand_harga, brand_lokasi dan brand_promosi dianggap konstan atau 0 maka loyalitas pelanggan di Zoya Cabang Medan akan menurun sebesar 16,244

b. Koefisien regresi produk sebesar 0,217 artinya apabila variabel produk ditambah $1 \%$ dan variabel yang lain di anggap tetap maka loyalitas pelanggan akan menurun sebesar $21,7 \%$

c. Koefisien regresi harga sebesar 3,772 artinya apabila variabel harga ditambah $1 \%$ dan variabel lain dianggap tetap maka loyalitas pelanggan akan meningkat sebesar $377,2 \%$.

d. Koefisien regresi lokasi sebesar 3,694 artinya apabila variabel lokasi ditambah $1 \%$ dan variabel yang lain di anggap tetap maka loyalitas pelanggan di Zoya Cabang Medan menurun sebesar 369,4\%.

e. Koefisien regresi promosi sebesar 0,966 artinya apabila variabel promosi ditambah $1 \%$ dan variabel yang lain di anggap tetap maka loyalitas pelanggan di Zoya Cabang Medan meningkat sebesar 96,6\%. 
f. Koefisien regresi brand image sebesar 0,900 artinya apabila variabel brand image ditambah $1 \%$ dan variabel yang lain di anggap tetap maka loyalitas pelanggan di Zoya Cabang Medan meningkat sebesar 90\%.

g. Koefisien regresi brand_produk sebesar 0,033 artinya apabila variabel brand_produk ditambah $1 \%$ dan variabel yang lain di anggap tetap maka loyalitas pelanggan di Zoya Cabang Medan meningkat sebesar 3,3\%.

h. Koefisien regresi brand_harga sebesar 0,215 artinya apabila variabel brand_harga ditambah $1 \%$ dan variabel yang lain di anggap tetap maka loyalitas pelanggan di Zoya Cabang Medan menurun sebesar 21,5\%.

i. Koefisien regresi brand_lokasi sebesar 0,245 artinya apabila variabel brand_lokasi ditambah $1 \%$ dan variabel yang lain di anggap tetap maka loyalitas pelanggan di Zoya Cabang Medan meningkat sebesar 24,5\%.

j. Koefisien regresi brand_promosi sebesar 0,030 artinya apabila variabel brand image ditambah $1 \%$ dan variabel yang lain di anggap tetap maka loyalitas pelanggan di Zoya Cabang Medan menurun sebesar 3\%.

\section{Kesimpulan}

Berdasarkan hasil analisis data yang telah dilakukan dapat disimpulkan bahwa:

1. Produk secara parsial berpengaruh signifikan dan positif terhadap loyalitas pelanggan. Nilai beta 0,223 atau $22,3 \%$ menunjukkan bahwa produk memiliki pengaruh sebesar 22,3\% terhadap loyalitas pelanggan Zoya cabang Medan.

2. Harga secara parsial berpengaruh signifikan dan positif terhadap loyalitas pelanggan. Nilai beta 0,357 atau 35,7\% menunjukkan bahwa harga memiliki pengaruh sebesar 35,7\% terhadap loyalitas pelanggan Zoya cabang Medan.

3. Lokasi secara parsial tidak memiliki pengaruh yang signifikan terhadap loyalitas pelanggan. Nilai beta 0,023 atau 2,3\% menunjukkan bahwa lokasi memiliki kontribusi sebesar 2,3\% terhadap loyalitas pelanggan Zoya cabang Medan.

4. Promosi berpengaruh signifikan dan positif terhadap loyalitas pelanggan. Nilai beta 0,211 atau $21,1 \%$ menunjukkan bahwa promosi memiliki pengaruh sebesar 21,1\% terhadap loyalitas pelanggan Zoya cabang Medan

5. Produk, harga, lokasi dan promosi secara simultan memiliki pengaruh yang signifikan dan positif terhadap loyalitas pelanggan Zoya cabang Medan. 
6. Produk, harga, lokasi dan promosi secara simultan memiliki pengaruh yang signifikan dan positif terhadap loyalitas pelanggan Zoya cabang Medan dengan brand image sebagai variabel moderasi. Artinya brand image mampu memoderasi pengaruh bauran pemasaran (4P) terhadap loyalitas pelanggan.

Dari beberapa kesimpulan di atas maka disarankan bagi butik Busana Muslim Zoya perlu mempertahankan brand image Zoya dengan sebuah citra yang kuat di benak pelanggan. Salah satu cara yang dapat dilakukan Zoya adalah membuat promosi yang gencar baik melalui media massa maupun media cetak. Dengan promosi tersebut diharapkan Butik Zoya memiliki citra yang kuat dalam benak pelanggan, dengan citra yang kuat akan menciptakan kepuasan pelanggan yang mendorong dan memelihara loyalitas dari pelanggan Butik Zoya itu sendiri. Dan dapat dilakukan penelitian selanjutnya dengan topik yang sama diharapkan dilakukan dengan objek penelitian yang berbeda yaitu pelanggan butik selain butik Zoya, dengan tujuan dapat melihat perbandingan loyalitas pelanggan dari beberapa merek. Peneliti diharapkan mampu menambah wawasan dan meningkatkan kemampuan menganalisis tentang ekonomi Islam khususnya pemasaran sehingga dapat memberikan kontribusi pemikiran.

\section{Catatan}

${ }^{1}$ Lilis Anggrian, Operational Leader Zoya Cabang Medan, Wawancara Pribadi, 21 April 2018.

${ }^{2}$ Ibid.

${ }^{3}$ Philip Kotler dan Kevin Lane Keller, Manajemen Pemasaran (Jakarta: Erlangga, 2009), hlm. 259.

${ }^{4}$ Butik Zoya, 21 April 2018.

${ }^{5}$ Bob foster, Manajemen Ritel (Bandung: Alfabeta, 2008), hlm. 174.

${ }^{6}$ Ratih Hurriyati, Bauran Pemasaran dan Loyalitas Konsumen(Bandung: Alfabeta, 2010), hlm. 129.

${ }^{7}$ Christopher H. Lovelock dan Lauren K. Wright, Manajemen Pemasaran Jasa, (Jakarta: Indeks, 2005), hlm. 133.

${ }^{8}$ Fitria Salahika Salma dan Ririn Tri Ratnasari, Pengaruh Kualitas Jasa Perspektif Islam Terhadap Kepuasan dan Loyalitas Pelanggan Grand Kalimas di Surabaya, (Surabaya: JESTT Universitas Airlangga, No. 4, II, 2015), hlm. 327.

${ }^{9}$ Buchari Alma, Manajemen Pemasaran dan Pemasaran Jasa(Bandung: Alfabeta, 2013), hlm.275.

${ }^{10}$ Valerie Zaithmal dan Bitner Mary Jo, Service Marketing (Singapura: The McGraw-Hill, 2000), hlm. 18.

${ }^{11}$ Philip Kotler, Manajemen Pemasaran terj. Alexander Sindoro dan Benyamin Molan (Jakarta: Prehalindo, 2000), hlm. 15.

${ }^{12}$ Philip Kotler dan Kevin Lane Keller, Manajemen Pemasaran ..., hlm. 4.

${ }^{13}$ Ita Nurcholifah, "Strategi Marketing Mix Dalam Perspektif Syariah", Journal of Islamic Studies, Vol. 4, No. 1, 2014, hlm. 79.

${ }^{14}$ Philip Kotler dan G. Armstrong, Dasar-Dasar Pemasaran...,hlm. 359.

${ }^{15}$ J. Paul Peter dan Jerry C. Olson, Consumer Behavior (Jakarta : Erlangga, 2000), hlm. 229. 
${ }^{16}$ Philip Kotler danKevin Lane Keller, Manajemen Pemasaran... hlm.76.

${ }^{17}$ Sutojo, Manajemen Pemasaran (Jakarta :Damar Mulia Pustaka, 2009), hlm 11.

${ }^{18}$ Rambat Lupioyadi, Manajemen Pemasaran Jasa: Teori danPraktik (Jakarta: Salemba Empat, 2001), hlm. 80.

${ }^{19}$ Jeni Raharjani, "Analisa Faktor-Faktor Yang Mempengaruhi Keputusan Pemilihan Pasar Swalayan Sebagai Tempat Berbelanja (Studi Kasus Pada Pasar Swalayan Di Kawasan Seputar Simpang Lima Semarang)", Jurnal Manajemen danOrganisasi, Vol. 2, No. 1, 2005, hlm. 14.

${ }^{20}$ Ratih Hurriyati, Bauran Pemasaran dan loyalitas Konsumen (Bandung: Alfabeta, 2005), hlm. 69.

${ }^{21}$ Fandi Tjiptono, Strategi Pemasaran (Yogyakarta: Andi, 2002), hlm. 49.

${ }^{22}$ Philip Kotler dan G. Armstrong, Dasar-Dasar Pemaaran ..., hlm. 219.

${ }^{23}$ Fandy Tjiptono, Brand Management and Strategy (Yogyakarta: Andi, 2005), hlm. 2.

54.

${ }^{24}$ Agus Suryana, Strategi Pemasaran untuk Pemula (Jakarta: Edsa Mahkota, 2007), hlm.

${ }^{25}$ A.B Susanto dan Himawan Wijarnako, Power Branding (Jakarta: Quantum Bisnis dan Manajemen,, 2004), hlm. 6.

${ }^{26}$ Fandy Tjiptono, Brand Management and Strategy..., hlm. 19.

${ }^{27}$ Suharsimi Arikunto, Prosedur Penelitian Suatu Pendekatan Praktek (Jakarta: Rineka Cipta, 2006), hlm. 130.

${ }^{28}$ Ibid.

${ }^{29}$ Iqbal Hasan, Pokok-pokok Materi Metodologi Penelitian dan Aplikasinya (Jakarta: Ghalia Indonesia, 2002) hlm. 61.

\section{Daftar Pustaka}

Alma, Buchari. 2013. Manajemen Pemasaran dan Pemasaran Jasa, Bandung: Alfabeta.

Arikunto, Suharsimi. 2006. Prosedur Penelitian Suatu Pendekatan Praktek, Jakarta: Rineka Cipta.

Foster, Bob. 2008. Manajemen Ritel Bandung: Alfabeta.

Hasan, Iqbal. 2002. Pokok-pokok Materi Metodologi Penelitian dan Aplikasinya, Jakarta: Ghalia Indonesia. . 2003. Pokok-pokok Materi Statistik 1 (Statistik Deskriptif) Edisi Kedua, Jakarta: Bumi Aksara. . 2005. Bauran Pemasaran dan loyalitas Konsumen, Bandung: Alfabeta.

Hurriyati, Ratih. 2010. Bauran Pemasaran dan Loyalitas Konsumen, Bandung: Alfabeta.

Kotler, Philip. 2000. Manajemen Pemasaran terj. Alexander Sindoro dan BenyaminMolan Jakarta: Prehalindo. . 2005. Bauran Pemasaran dan loyalitas Konsumen, Bandung: Alfabeta. dan G. Armstrong. 2001. Dasar-Dasar Pemasaran Jakarta: Indeks Gramedia. 
dan Kevin Lane Keller. 2009. Manajemen Pemasaran, Jakarta:

Indeks.

Lovelock, Christopher H dan Lauren K. Wright. 2005. Manajemen Pemasaran Jasa, Jakarta: Indeks.

Lupioyadi, Rambat. 2001. Manajemen Pemasaran Jasa: Teori danPraktik, Jakarta: Salemba Empat.

Peter, J. Paul dan Jerry C. Olson. 2000. Consumer Behavior, Jakarta: Erlangga.

Suryana Agus. 2007. Strategi Pemasaran untuk Pemula, Jakarta: Edsa Mahkota.

Susanto, A.B dan Himawan Wijarnako. 2004. Power Branding, Jakarta: Quantum Bisnis dan Manajemen.

Sutojo. 2009. Manajemen Pemasaran, Jakarta :PT. Damar Mulia Pustaka,.

Tjiptono, Fandi. 2002. Strategi Pemasaran Yogyakarta: Andi.

Zaithmal, Valerie dan Bitner Mary Jo. 2000. Service Marketing Singapura: The McGraw-Hill.

Nurcholifah, Ita, "Strategi Marketing Mix Dalam Perspektif Syariah”, Journal of Islamic Studies, Vol. 4, No. 1, 2014.

Raharjani, Jeni, “Analisa Faktor-Faktor Yang Mempengaruhi Keputusan Pemilihan Pasar Swalayan Sebagai Tempat Berbelanja (Studi Kasus Pada Pasar Swalayan Di Kawasan Seputar Simpang Lima Semarang)”, Jurnal Manajemen dan Organisasi, Vol. 2, No. 1, 2005.

Salma, Fitria Salahika dan Ririn Tri Ratnasari, "Pengaruh Kualitas Jasa Perspektif Islam Terhadap Kepuasan dan Loyalitas Pelanggan Grand Kalimas di Surabaya", JESTT Universitas Airlangga, Vol. II, No. 4, 2015.

Wawancara dengan Ibu Lilis Anggrian, Operational Leader Zoya Cabang Medan, 21 April 2018. 